\title{
Ancient Audacity---Did Sages Past Subconsciously Speak Of Cellular Dust?
}

\author{
Mister Seun Ayoade \\ Independent Researcher. Alumnus, College of Medicine University of Ibadan, Oyo State, Nigeria
}

Corresponding Author: Mister Seun Ayoade, Independent Researcher. Alumnus, College of Medicine University of Ibadan, Oyo State, Nigeria.

Received Date: November 13, 2021; Accepted Date: December 30, 2021; Published Date: January 06, 2022

Citation: Mister Seun Ayoade, (2022) Ancient Audacity---Did Sages Past Subconsciously Speak Of Cellular Dust?. J. Immunology and Inflammation Diseases Therapy. 5(1); Doi:10.31579/2637-8876/020

Copyright: (C) 2022 Mister Seun Ayoade. This is an open-access article distributed under the terms of The Creative Commons Attribution License, which permits unrestricted use, distribution, and reproduction in any medium, provided the original author and source are credited.

\begin{abstract}
:
"Would it be too bold to imagine, that in the great length of time, since the earth began to exist, perhaps millions of ages before the commencement of the history of mankind, would it be too bold to imagine, that all warm-blooded animals have arisen from one living filament, which THE GREAT FIRST CAUSE endued with animality, with the power of acquiring new parts, attended with new propensities, directed by irritations, sensations, volitions, and associations; and thus possessing the faculty of continuing to improve by its own inherent activity, and of delivering down those improvements by generation to its posterity, world without end!
\end{abstract}

Keywords : cellular dust hypothesis; microzymian theory

\section{Introduction}

"Would it be too bold to imagine, that in the great length of time, since the earth began to exist, perhaps millions of ages before the commencement of the history of mankind, would it be too bold to imagine, that all warm-blooded animals have arisen from one living filament, which THE GREAT FIRST CAUSE endued with animality, with the power of acquiring new parts, attended with new propensities, directed by irritations, sensations, volitions, and associations; and thus possessing the faculty of continuing to improve by its own inherent activity, and of delivering down those improvements by generation to its posterity, world without end!

Erasmus Darwin (12 December 1731 - 18 April 1802) Grandfather of Charles Darwin.

"For that which befalls men befalls beasts.....as men die so die beasts....all are of dust and all turn to dust again"- Solomon The Wise [Ecclesiastes 3: 19-20]

According to the cellular dust hypothesis/microzymian theory of origin/germ terrain duality theory all living things and the universe they inhabit owe their existence to the activity of microscopic entities called microzymas or cellular dust. These living entities exist in all human beings and animals and when any such living thing perishes the minuscule entities depart. Did Ancient philosophers somehow subconsciously know of these things by "gut feeling"/instinct even though they could not see them with their naked eyes? Long before the invention of the microscope and even when the microscope was in its infancy, philosophers spoke of entities and invisible processes. They spoke, it would appear, of cellular dust. This is food for thought.
1. Confucius spoke of a "single source" which gradually unfolded and branched to create life.

2. Leucippus of Miletus and Democritus of Abdera 430 BC spoke of an invisible and indivisible entity called "atomos". Democritus said these "atomos" were moving all around us. The word "atom" is derived from this word.

3. Epicurus 341-270 BC spoke of "swerving" atoms

4. Aristotle (384-322 BC) spoke of pneuma, a "vital heat" that made life.

5. Plotinus spoke of "one" thing that resembled nothing but transcended all things living or non-living.

6. Xenophanes of Colophon spoke of wet and dry interactions producing life.

7. Empedocles spoke of attractive and repulsive forces that acted on earth, wind, water and fire.

8. Thales said life arose from the water.

9. Anaximander spoke of life-giving mud.

10. Diogenes said all things were the same in essence.

11. Anaxagoras' theory is the closest to the Cellular Dust Hypothesis. He said germs in the atmosphere made all life.

12. Sir Isaac Newton spoke of invisible "active particles" of life.

\section{WHICH CAME FIRST, THE CHICKEN OR THE EGG?}

To the evolutionist there can be no doubt about it-the egg came first. The simple evolved to the complex. To the creationist the chicken came first. It was created the chicken and subsequently laid the egg. To the cellular 
dust hypothesist it could have gone either way and the chicken and the egg could even have appeared simultaneously depending on the activity of the microzymas.

\section{SPARKS AND FLASHES, SIGHTS AND SOUNDS}

It has been said that a zinc spark occurs when the spermatozoa and ovum form the zygote i.e. at the exact moment of conception. Light is a form of energy and the beginning of the coordination of microzymas is likely the catalyst of the spark. Do lights dim or spark at the point of death? Are there attendant sounds, subsonic small bangs? More research needs to be done. An index of all body processes and resultant sparks (intensity, frequency and duration) ought to help scientists better understand the microzymas and energy expended thereof. Alternative biological forms of lighting or heating could be devised by mimicking such processes. Cellular dust activity during bioluminescence should also be studied. [15]

\section{BABESIOSIS VALIDATES THE GERM TERRAIN DUALITY THEORY}

Babesiosis is a zoonotic parasitic infection transmitted by the Ixodes tick, currently gaining ground in Europe and in the USA. But studies have shown that the sickle cell condition provides resistance to babesiosis. How?

The Germ-Terrain duality theory of disease states that the etiology of certain diseases/diseased states is better explained as a complex interplay between germs and the inherent anatomical/physiological integrity of the body cells.

It argues that the etiology of certain diseases is not fully explained merely by the presence of germs (Germ Theory) or by a mere loss of cellular integrity (Terrain Theory). As a result the prevention and treatment of such diseases should focus not just on fighting germs but on maintaining/restoring the anatomical/physiological cellular integrity. The Germ-Terrain duality theory is a harmonization of the current Germ Theory (popularized by Louis Pasteur) and the hitherto discarded Terrain Theory (popularized by Pierre Bechamp).

The sickle cell has a reduced surface area compared to normal cell thus reducing negative effect of babesiosis germ. Other telltale thallasemia examples include-

\begin{tabular}{|l|l|l|}
\hline Abnormal haemoglobin & Anatomical/Physiological Aberration & Disease Resisted Thereby \\
\hline S & $\begin{array}{l}\text { Sickle shaped cells; base substitution of glutamic acid with valine in beta } \\
\text { chain }\end{array}$ & Malaria, Babesiosis, Toxoplasmosis \\
\hline C & Forms crystals; base substitution of glutamic acid with lysine in beta chain & Malaria \\
\hline D & Mutation on codon 121 & Malaria \\
\hline E & Point mutation at position 26 of glutamic acid to lysine & Malaria \\
\hline Lepore & Crossover between delta and beta chains & Malaria \\
\hline F & 2 alpha, 2 gamma structure & Malaria \\
\hline Persistent F & As above & Malaria \\
\hline J & Alpha globin variation & Malaria \\
\hline O & Mutation at codon 121 & Malaria \\
\hline G & Alpha chain mutation & Malaria \\
\hline Hasharon & Alpha and beta chain mutation & Malaria \\
\hline M & Beta globin gene codon 92 & Malaria \\
\hline Hope & Alpha and beta chain mutation & Malaria \\
\hline Pisa & Protein related & Malaria \\
\hline N-Baltimore & Protein related & Malaria \\
\hline I & Protein related & Malaria \\
\hline Hopkins - & Histidine replaced with aspartic acid & Malaria \\
\hline Bart & Alpha globin gene dysfunction & Malaria \\
\hline
\end{tabular}

\section{GENES AND GENETIC MUTATIONS THAT VALIDATE THE GERM TERRAIN DUALITY THEORY}

Cystic fibrosis, sickle cell anemia, Tay-Sachs disease, phenylketonuria and color-blindness are diseases caused by gene mutations. Just like the mutation of genes causes diseases, other gene mutations actually protect from and mitigate other diseases. Both the causation and protection from diseases by genes and mutations thereof [which are a function of the human terrain] validate the germ terrain duality theory of disease. [6-11]

\begin{tabular}{|l|l|}
\hline Gene/ Terrain Parameter & Effect i.e. disease said factor causes protection/amelioration from \\
\hline NOS2 gene mutations & Malaria and cytomegalovirus [CMV] pneumonitis and encephalitis \\
\hline RAB7A & Covid \\
\hline Delta 32 mutation of C-C chemokine receptor type 5 & HIV Type 1 \\
\hline SLC30A8 gene mutation & Diabetes \\
\hline adiponectin gene ADIPOQ Gene deletion & inflammation of arteries \\
\hline mutation in the cholesteryl ester transfer-protein gene CETP & protection against both high cholesterol levels and cognitive disorders \\
\hline mutations in the gene SGK1 & reduces risk of Parkinson's disease \\
\hline mutations in prion protein gene, PRNP & protection from kuru [Creutzfeld Jakob -like Disease] \\
\hline
\end{tabular}




\section{REFERENCES}

1. When Sperm Meets Egg Watch the remarkable "flash" at the moment of fertilization.

2. When Sperm Meets Egg Watch the remarkable "flash" at the moment of fertilization. BY JIM FESTANTE MAY 01, 2016

3. Scientists Just Captured The Flash of Light That Sparks When a Sperm Meets an Egg

4. Scientists Just Captured The Flash of Light That Sparks When a Sperm Meets an Egg BEC CREW27 APRIL 2016

5. Fertilized human egg emits microscopic flash of light

6. Ayoade S. Germ-terrain duality of sickness, equivalent of wave-particle duality of light for the biological sciences? Bechamp revisited. Int J Anat Var. 2017;10(1):010-11

7. Mister Seun Ayoade. The Differences between the Germ Theory, the Terrain Theory and the Germ Terrain Duality Theory; JOJ Nurse Health Care. 2017; 4(2): 555631

8. Mister Seun Ayoade. The Differences between the Germ Theory, the Terrain Theory and the Germ Terrrain Duality Theory; JOJ Nurse Health Care. 2017; 4(2): 555631

9. Genetic Shield Found for Malaria
10. Robust adaptive immune response against Babesia microti infection marked by low parasitemia in a murine model of sickle cell disease Woelsung Yi,1,* Weili Bao,1,*Marilis Rodriguez,2, $\uparrow$ Yunfeng Liu, $1, \dagger$ Manpreet Singh,2 Vijendra Ramlall,1 Jeny R. Cursino-Santos, 2 Hui Zhong, 1 Catherine M. Elton,3 Gavin J. Wright,3 Avital Mendelson,1 Xiuli An,4 Cheryl A. Lobo,2 and Karina Yazdanbakhsh 1Haematologica. 2019 Nov; 104(11): 2189-2199. Prepublished online 2019 Mar 28. doi: 10.3324/haematol.2018.214304

11. Altered parasite life-cycle processes characterize Babesia divergens infection in human sickle cell anemia Jeny $\mathrm{R}$. Cursino-Santos,1 Manpreet Singh,1 Eric Senaldi,2 Deepa Manwani,3 Karina Yazdanbakhsh,4 and Cheryl A. Lobo1 PLoS Pathog. 2013 Jul; 9(7): e1003387. Published online 2013 Jul 11. doi: 10.1371/journal.ppat.1003387
This work is licensed under Creative Commons Attribution 4.0 License

To Submit Your Article Click Here:

Submit Manuscript
Ready to submit your research? Choose Auctores and benefit from:

$>$ fast, convenient online submission

$>$ rigorous peer review by experienced research in your field

$>$ rapid publication on acceptance

$>$ authors retain copyrights

$>$ unique DOI for all articles

$>$ immediate, unrestricted online access

At Auctores, research is always in progress.

Learn more https://auctoresonline.org/journals/immunology-andinflammation-diseases-therapy- 